\title{
Multiperspectivism in the Novels of the Spanish Civil War
}

\author{
Hans Lauge Hansen, Aarhus University
}

\begin{abstract}
Since the turn of the millennium, Spanish society has been engaged with an intense public and political debate about the Civil War and the post-war period. The number of publications has exploded within all genres, and narrative fiction clearly participates in the negotiation of the cultural memory of this period. Taking its point of departure in Todorov's concept of restorative narratives, this article investigates whether contemporary Spanish novels continue a Manichaean division between 'us' and 'them', and whether it is possible to detect a difference in narrative patterns before and after the turn of the millennium.
\end{abstract}

Keywords: cultural memory, Spanish Civil War, restorative narrative, multiperspectivism, Spain.

Since the turn of the millennium, Spain has witnessed a renewed public and political debate about Spain's history in the twentieth century which has focused particularly on the memory of the Civil War of 1936-1939 and the immediate post-war period. The number of publications dedicated to this issue has exploded, not only in historiographic discourse, but within all genres, including novels, biography and autobiography. ${ }^{1}$ Through dialogue with other social discourses, narrative fiction clearly participates in the construction of the cultural memory of a given society. But what is the nature of this involvement? This article engages this question by examining the change in narrative perspective in the contemporary Spanish novel and by discussing the possible cultural and social impact of this change.

The public debate on the Civil War in Spain has on the one hand been driven by polemic right-wing writers and historians ${ }^{2}$ who have tried to justify the Nationalist uprising against the Republic in July 1936 by claiming that the Spanish Civil War did not start with this Nationalist rebellion, but was rather triggered by the extreme left as early as 1934, and that Franco's military coup was a necessary intervention to prevent a socialist revolution. 
While this ideological position has been contested by renowned historians like Javier Tussell and Santos Juliá, it has nevertheless drawn a lot of public attention to the issue of historical interpretation. On the other hand, the socialist party PSOE (Partido Socialista Obrero Español), which was reduced to the role of political opposition after the elections of 1995, supported a popular movement that claimed the right to know what really happened during and after the war. When they regained power after the elections of 2004, the socialists passed the act on 'The Recovery of the Historical Memory' in the Spanish parliament in 2007 authorizing the exhumations of Civil War mass graves and the identification of victims that continue to this day. These activities, along with the subsequent charge brought by exFalangists against Spain's leading judge, Balthazar Garzón, accusing him of breaking the 1977 amnesty law through his investigation into those responsible for the mass murders committed during the Civil War, have resulted in even more public attention and debate. These events constitute the cultural and political context for the current renewed artistic interest in the question of the Spanish Civil War in film and the novel.

It is relevant to ask to what degree these narratives contribute to the recovery of the historical memory, and what kind of implications we might expect literary discourse to have. In his seminal study of 2005, José Colmeiro describes the period leading up to the turn of the millennium as representing a quantitative inflation and a qualitative devaluation of memory (Colmeiro $2005,19)$. The majority of the overwhelming number of cultural products dedicated to the topic of cultural memory which have come onto the market are, according to Colmeiro, the reverse of the collective oblivion that characterized the period of transition from dictatorship to democracy. They are the result of 'a memorialistic and museistic obsession ... typical for the postmodernist collector of souvenirs' (p. 22); in other words, cultural merchandise without lasting value or social effect. On the other hand González García thinks that 'in the last few years literature has played an eminent role in recovering the memory of many painful facts of the Civil War' (González García 2009, 182). This is, however, not the place to settle this twist, or to solve the problem as such. ${ }^{3}$ In what follows I will focus on one specific feature, namely the narrative perspective on 'us' and 'them' and the distribution of 'good' and 'evil'.

In a recent article, Tzvetan Todorov raises the question of whether collective memory and the narration of past events have social effects; 
specifically, he asks whether they contribute to the avoidance of future evil. He concludes that 'the memory of the past serves no purpose if it is used to build an impassable wall between evil and us - we who identify exclusively with irreproachable heroes and innocent victims and seek to drive the agents of evil outside the confines of humankind' (Todorov 2009, 448). According to Todorov, all narratives contain the production of evil and good, along with two sets of protagonists: the villain and his victim, and the hero and his beneficiaries. The hero and the victim are regarded with respect, while the villain and the passive beneficiaries are held in low esteem (p. 449). If we add to this scenario the distinction between $u s$, the community of the good, and the others, the enemies, we have, still according to Todorov, the basic pattern upon which most collective memories are built. Restorative narratives, on the other hand, seek to change this identification with heroes or victims and the extreme distance we put between the miscreants and ourselves. Bringing this distinction to bear on post-millennial Spanish literature, then, we might ask whether contemporary Spanish narratives continue a Manichaean division between us and them, and whether it is possible to detect a difference in the narrative patterns before and after the turn of the millennium.

A significant proportion of the novels in question can be characterized as historiographic metafiction ${ }^{4}$ in the sense that they include the creative process as a kind of frame narrative, either as part of the process of investigation and writing, something we might call a 'mimesis of interpretation', or as a part of the individual recollection, which would equal a 'mimesis of memory'. Research dedicated to the new historical novel in Spain has typically been limited to the 1980s and 1990s (Albert, Fernández Prieto, Oleza Simó, Kohut, Pulgarín), although David Herzberger's contribution to the study of fiction and historical writing in post-war Spain should also be mentioned. Research on the novelistic experience of the Spanish Civil War is mainly limited to the period until 1990 (Ponce de León, Gogorza Fletcher and Bertrand de Muñoz). Since the turn of the millennium, three major contributions have been published: the dissertations of Ana Luengo (2004) and Carmen Moreno-Nuño (2006), along with the book by José Colmeiro mentioned above (2005). However, these studies have primarily limited themselves to the study of novels published before the turn of the millennium. Interestingly, all three studies also confirm the hypothesis that the axiological point of view represented 
in these novels is that of the Republican side (the $u s$ ) and that the role of the 'villains' is played by the Nationalist side.

In the novels published after the turn of the millennium, the narrators are not as attached to past experiences as their predecessors were (Cossalter 2006, 365; Cuñado 2007, 4), and the best of this literature has not only lost the fear of a political backlash, it has also left political radicalism behind, which opens history up to new investigations (Gracia García 2008, 248). As a consequence, the point of view of the narrator has changed in comparison to the point of view of the so-called 'new historical novel' in Spain. Jordi Gracia García has put it in this way: the generation brought up under democracy does not share the apocalyptic vision of liberation and revolution that characterized their parents, and they might learn from the liberal point of view, present in Spain even during the dictatorship. During the first fifteen years of the Francoist regime many Spanish intellectuals, writers and artists maintained a silent resistance to the dictatorship, and this group, not the fighting 'heroes', represents, according to Gracia García, the point of view of the present revision of the Spanish recent past (Gracia García 2004, introduction). Strictly related to this observation, it is significant to notice that a certain proportion of the novels seem to break with the exclusively Republican point of view that dominated the narratives published before 2000. In its place we find a predominant multiperspectival point of view that allows for a more varied comprehension of the social and political issues in question.

The means by which this multiperspectival point of view is construed are quite different, and in the following I will analyse four different ways by which this effect is obtained. Of course, the novels chosen do not constitute a statistically defensible sample, and other novels published during the same decade, such as Dulce Chacón's La voz dormida (2002) or Carlos Fonseca's Tiempo de memoria (2009), continue to follow the narrative patterns of the transitional period. Nonetheless, I do think that the novels I will analyse here represent a general trend.

\section{Breaking with the image of the traditional Nationalist villain}

After four decades of official representation of the Civil War as a crusade of the good Nationalists against the evil monsters of communism, the 
Spanish narratives of the eighties and nineties inevitably and unanimously identified with the Republican side, while the Nationalist side became the evil 'other'. This being the case, it is remarkable that a significant proportion of the Spanish novels of the last decade engage with the challenge of representing the Nationalist 'other' in a more subtle way. This is being done in many ways, from Miguel Dalmau's radical examination of the mind of the Falangist collaborator in La noche del Diablo (2009) and the balanced interchange between characters from the Nationalist and Republican sides in Pedro Corral's La ciudad de arena (2009), to the discrimination of different tendencies within the Nationalist block in Nacho Guirado's La lista de los catorce (2009) - on the one hand ethically reflected, honest people and on the other hand criminal bandits.

Javier Cercas's novel Soldados de Salamina (2001) has become a trendsetter among representations of 'the other side' of the war in literature. In this novel, the narrator, an aspiring writer named Javier Cercas, sets out to write a narrative about a historical Francoist figure, the author Rafael Sánchez Mazas. The narrator does not set out to write a novel; his ambition is to write the allegedly 'true story' about this person. The narrator is first and foremost fascinated by the fact that Rafael Sánchez Mazas, one of the co-founders of the Falange española in the thirties, was captured by the Republicans during the war, but managed to escape right under the nose of the firing squad. According to the legend, he managed to do so with the help of a Republican soldier who saw him, but who did not denounce him in the subsequent persecution. The novel exhibits the characteristics of historiographic metafiction, with the plot divided between the reconstructed past and the process of investigation situated in the present. The first and third chapters are dedicated to the process of investigation, while the second chapter reproduces the narrator's first manuscript about Sánchez Mazas's story in the past. While the story about the process is dynamic and interesting, the second chapter does not seem to engage the reader in the same way, although the story does have a clear dramatic plot. The narrator is well aware of this problem, but he is not able to find the solution until the last pages of the book. (The observant reader, however, might discover a clue in the first chapter and the first part of the third chapter.) 
Throughout the first chapter of the novel the narrator persistently insists on two things: first, that he wants to write a story about a former Falangist and not about one of the usual Republican 'heroes', and, second, that he wants to write a 'true story' (relato real), not fiction. The resemblance of the character of the narrator to the empirical author imbues the words of the former with a certain amount of authority in the eyes of the innocent reader, but the naïve simplicity of the narrator's intentions, especially that of producing a 'true story', is repeatedly belied by the very process of investigation which is disclosed during the chapter. As part of the reconstruction of the 'true story', the narrator discovers eight different versions of the story about Sánchez Mazas's escape from the firing squad, of which only a few are compatible; and when he looks at the record of Sánchez Mazas's own testimony very closely, the narrator is forced to recognize that 'what Sánchez Mazas had told his son (and what he told me) was not what he remembered had happened, but what he remembered he had told before' (Cercas 2001, 43; my translation). Thus the implied author problematizes the relation between memory and imagination, between history and fiction, and he exposes the naïve and simplistic attitude of his own narrator (Satorras Pons 2003, 233; Gómez Trueba 2009, 72). Acknowledging this ironic distance between the implied author and the narrator is imperative for the reader's understanding of the complex exploration of the role of the 'hero' in the text.

The narrator's first version of the story, which focuses on Sánchez Mazas as the object of study and is written in a factual, biographical style, is reproduced in the second part of the book, and is entitled 'Soldados de Salamina' just like the novel as a whole. After the narrator has finished this version of the story, he decides to reread it himself, and the third part of the novel begins with his own critique of this first version. Among other things he says:

The book was not bad, but incomplete, like a finished mechanism that was not able to fulfil the function it was created to fulfil, because a piece was missing. The bad thing was that I did not know what piece it was. I improved the book in a fundamental way, I rewrote the beginning and the end, I rewrote various episodes and moved them around. But the piece did not appear. The book was still lame. (Cercas 2001, 144; my translation)

The narrator is frustrated and confesses his doubt to his girlfriend, Conchi, a younger girl whom the narrator treats in a patronizing way, as 
if she were some kind of a bimbo. And contrary to the arrogant expectations of the narrator, Conchi's answer is not at all stupid: '- Shit! Conchi said. Didn't I tell you not to write about a Fascist? These people fuck up everything they touch. What you have got to do is to forget all about this book and begin to write another. How about one on García Lorca?' (p. 144; my translation). Conchi's diagnosis turns out to be correct, although her suggested cure is too simple. During the third part of the novel, the narrator finds the missing narrative piece in the figure of the old volunteer Miralles, who may be, or may not be, the militiaman who found, but did not denounce, Sánchez Mazas when he fled from the firing squad. The narrator decides to go to the asylum in the south of France where Miralles lives to interview him, but he does not get any conclusive answer to his fundamental question. Nevertheless, on the train home, the narrator sees himself reflected in the window and realizes that he has found the missing piece: 'there, I suddenly saw my book ... I saw it as a whole, finished, from the start to the end, from the first to the last line' (p. 208; my translation). On the train, he acknowledges that he himself, his subjective perspective and his struggle with the narrative material, is an inescapable part of the story (Amago 2006, 162-163), and that this subjective angle has permitted him to find another kind of hero, not an ideologically engaged and eloquent individual hero like Sánchez Mazas or García Lorca, but the average, anonymous citizen who has done his best to do his duty, and who has acted ethically correctly at a decisive moment in history. And because of this almost collective character of his new hero, it does not really matter whether the man who did not denounce Sánchez Mazas was Miralles or not; what matters is that the narrator's own discourse, the literary discourse, is able to save this man's deed and his story from oblivion: '[T]here I realised ... that as long as I told his story, Miralles would in a way be kept alive, and that [here follows a lot of names of the Republican characters from the novel, HLH] would still be alive although they were dead, dead, dead a long time ago' (Cercas 2001, 208; my translation). The replacement of the ideologically determined Sánchez Mazas as the object of study by the anonymous militiaman Miralles implies that facts and certainty, so essential to the journalistic discourse of biography, have been replaced by indeterminacy and lack of certainty in the literary discourse that dominates the third part of the novel. 
In this way the empirical author Javier Cercas has managed to use his somewhat naïve alter ego, the character-narrator Javier Cercas, to renovate the genre of the historical novel in several ways. He explains in narrative form the importance of the recovery of historical memory in Spain, while at the same time disclosing the problematic nature of historiography and its close affinities to narrative (Amago 2006, 198). But what is even more important in this context is the fact that Cercas breaks the taboo of writing about a character belonging to the Nationalist bloc, and that he at the same time engages the reader in a metareflection on the figure of the hero in contemporary historical fiction.

\section{The point of view of the non-belligerent majority}

As mentioned above, a certain number of these novels have adopted the point of view of the non-belligerent majority, but contrary to Todorov's narrative template, the novels do not denigrate these people because of their passive attitude. Instead these novels conceive of them as victims who were just trying to live their lives in spite of the chaos created by the conflicting minorities. A series of novels, including Fonseca's Tiempo de memoria and Cercas's Soldados de Salamina, contains the commonplace of the devastated parents who are informed of the death or execution of their sons, while others try to describe the living conditions for ordinary people during the war. This is the case in Muñoz Molina's La noche de los tiempos (2009), in which the protagonist is a devoted Republican who, because of his mature age, does not feel compelled to take up arms, but prefers to escape.

In Alberto Méndez's Los girasoles ciegos (2004) the character of the deserter represents the perspective of the non-belligerent individual, victim of the two belligerent minorities. Méndez's book is divided into four short stories, entitled four 'defeats', which are linked together so that the protagonist of the first story reappears as a subordinate character in the third story, and the protagonist of the second story reappears in the last one. The protagonist of the first story, Captain Carlos Alegría, is a Nationalist soldier who decides to become a deserter the day before the surrender of Madrid in 1939, because, as he says, the Nationalist forces do not want to win the war; they just want 
to kill the Republicans (Méndez 2004, 28). The Republicans do not trust him, and he is confined, and when the Nationalists enter Madrid the next day, he is arrested. After a brief military trial he is given the death sentence for treason and executed, but he miraculously survives and escapes. In the 'third defeat', the character of Carlos Alegría suddenly reappears in 1941 in a jail dedicated to the interrogation and conviction of 'war criminals', where dozens of death sentences are passed every day. But one day Alegría captures a rifle from one of the wardens, declaring that he has never killed anybody, and commits suicide (p. 90).

The story introduces a fundamental theme of the book, the supremacy of human decency and integrity over survival, and suffering as a human condition: Carlos Alegría prefers to desert the victorious army when he realizes that the war is not a question of winning, but a question of killing the political adversary; and later he prefers to commit suicide in order not to owe anything to the regime. This theme is rearticulated in two of the three other stories. In the second 'defeat', a young Republican poet, hiding in the mountains after the war, chooses to sacrifice his newborn son and take his own life instead of turning himself in to the authorities. In the third 'defeat', a Republican soldier keeps himself alive for weeks in the jail by inventing stories about the commanding officer's son, convicted and executed in a Republican jail during the war; but after having witnessed Carlos Alegría's ethically motivated suicide, he decides to confess the truth, knowing that he, like Scheherazade, will be killed when he stops telling stories. He admits that the officer's son was executed not as a Nationalist martyr, but as a common civilian criminal, and is himself executed the next day.

Yet another means of construing the perspective of the non-belligerent citizen is to adopt the point of view of the innocent child. The commonplace of the child of the refugee, whether the maquis in the mountains as in Isaac Rosas's La mala memoria (1999) or the refugee hidden in a shelf inside the house, the 'toad', as in the last 'defeat' in Mendez's Los girasoles ciegos, invites the reader to identify the root of the conflict, the ideological conviction and political engagement, as something alien to the child's basic human needs and concerns: parental love and family care. In both cases the child becomes involved in the discovery of the refugee, and must, in addition to the tragedy of losing 
his father, live the rest of his life with the guilt of having betrayed his own blood.

The point of view of the non-belligerent citizen - the parents of the executed victims, the deserters and the children - tends to represent the war, not in terms of a battle between good and evil, but rather as an ethical challenge related to the violation of the fundamental conditions for the lives of average human beings.

\section{Representation of the evil of the Republican side}

An important aspect of the public debate about the Civil War instigated by the political right has centred on the revelation of the atrocities committed by the Republicans during the war. An exceptionally painful and important incident in this respect was the assassination of several thousand prisoners considered to be Nationalist sympathizers, in the cemetery of Paracuellos outside Madrid in November and December 1936. While the episode has been publically known since 1940, it gained renewed interest with the publications of books by Vidal (2004) and Payne (2006). Now, a series of authors seem to believe that it is important that these episodes are recollected and integrated in the process of cultural memory, in order not to leave the interpretation of the question to right-wing propaganda. The crimes committed behind the Republican lines as a result of the conflict between communists and anarchists has been documented by (among others) George Orwell in his Homage to Catalonia (1938), and with the publication of Ignacio Martínez de Pisón's Enterrar a los muertos (2005) Spain gained its native narrative account of the assassinations committed by the Soviet secret police in Spain. The most recent account within literary fiction has been Antonio Muñoz Molina's La noche de los tiempos (2009).

After having dedicated most of his writing since the turn of the millennium to hybrid works between the novel and the essay (Sefarad, 2001), between the novel and the diary (Ventanas de Manhattan, 2004, and Días de diario, 2007), or between novel and autobiography (El viento de la luna, 2006), Muñoz Molina returned to the form of the classical novel with La noche de los tiempos in 2009. Almost 1,000 pages long, this novel is without doubt his most ambitious project of the decade, and will most likely come to stand as an emblematic representative of the new historical 
novel dedicated to the recovery of historical memory in Spain. As is characteristic of Muñoz Molina's work, this novel breaks in a number of ways with the generic traits that have come to characterize the 'new' historical novel by returning to a more classical narrative form. Unlike many of the novels discussed above, there are no overt metafictional reflections upon the novel as a novel in La noche de los tiempos, and there is no division of the plot according to the postmodern tradition of historiographic metafiction; instead, there are only subtle indications of the present moment of writing through the interventions of a classical explicit narrator, interventions that are most pronounced in the last half of the book. The hybridization of genres and discourses in the form of the inclusion of historical documents or newspaper articles so prevalent in the other novels is also absent.

The reader meets the protagonist, a renowned Spanish architect named Ignacio Abel, as a refugee in Pennsylvania Station in New York in 1937. Already here the novel differs from the traditional Cainistic tale of the Civil War: Abel did not get killed; he fled. He has fled the Spanish Civil War, and he has left his wife and his two children behind, basically because he has fallen in love with a young American girl called Judith. He became acquainted with the girl in Madrid in 1935, a year before the outbreak of the war, and they became lovers. While he was falling in love with the girl, the situation grew still more unsustainable, and in July 1936 the Nationalist rebellion and subsequent socialist/anarchist uprising in Madrid coincided with the collapse of Abel's marriage and the girl's disappearance. When he finds a job opportunity abroad which allows him to follow Judith, he does not hesitate; he leaves everything behind.

The novel is constructed as a mimesis of memory (Neumann 2008, 334) in the sense that the first 800 pages or so cover Abel's memories while he is riding the train from New York to a small town called Rhineberg, only a few hours away. Abel is a complex character who combines some very sympathetic characteristics - he is intelligent, handsome, cultivated and in love - with some typical traits of the anti-hero: he cheats on his wife, he lies, and he is personally and politically a coward. He is a man who finds himself in the chaotic centre of world politics, but for whom the most important thing in the world is to find his beloved. In short: he is first and foremost very human, and in this respect he incarnates the point of view of the average, non-belligerent citizen. $\mathrm{He}$ is a member of the socialist party, 
and as such he is actively engaged in the development of the Republic and a supporter of the People's Front in the spring of 1936, but when things get tough, he backs out. He is the chief architect in charge of the construction of the new campus of the Complutense University, but when the workers strike and the construction site is later converted to a combat zone, he seems to lose his former identity. The combination of this weak and deceitful character with a narrative which is told as a kind of fiction of his personal, subjective memory renders the interpretation of the discourse a multifaceted challenge, worthy of much scholarly attention. In the following discussion, however, I will narrow my focus to the perspective that is relevant for this article: the representation of the violence on the Republican side.

Ignacio Abel's experience of the first months in a besieged Madrid is absolutely horrible, not only because of the bombings and the shortage of food and other daily necessities, but first and foremost because of the intolerable harassment and random violence imposed by the various armed militias belonging to different left-wing organizations and syndicates. In the months leading up to the Nationalist insurrection, a series of assassinations is committed in Madrid on both sides, and after the outbreak of the war, state power breaks down and the militias take over the control of the streets. In this situation some of the anarchist construction workers from the building site, armed and scarcely uniformed, look up Ignacio Abel one night, and he is taken for a 'stroll'. Only by coincidence is he saved by a socialist foreman in the very moment they are going to execute him. Later, his friend and former teacher at the Bauhaus School in Germany, Professor Rossman, who is now a German refugee in Madrid, is arrested by the communists. In this politically infected environment, Ignacio Abel begins a search for his friend in which he uses his contacts with the cultural elite in Madrid, but without results. Professor Rossman has already been liquidated by the Russian secret police.

La noche de los tiempos is by no means an argument in favour of the Nationalist insurrection; on the contrary, it refuses to accept the use of violence as a solution to political problems. But at the same time it refuses to ignore the flaws and problems that exist on the Republican side, and it seeks to demystify famous icons of the Republican cause, including Federico García Lorca, Rafael Alberti and José Bergamín. In this sense the novel insists on the ambiguous and complicated character of social reality: 
the responsibility for the outbreak of the Civil War is clearly placed with the Francoist forces and the novel denounces the evident hypocrisy of the democratic powers' refusal to support the Spanish Republic, but at the same time the novel refuses to depict the war as a conflict between heroes and villains, between Good and Evil. I think that we, in this respect, can take Ignacio Abel's words as a reliable expression of the implicit author's point of view, when he in the last conversation with Judith expresses the following position:

— [Judith]: The army and the Falangists have risen against the Republic. It is only because of the help of Mussolini and Hitler that they have not yet been defeated.

- Now, again you sound like you were standing on a podium in a meeting.

- Is it not the truth I am saying?

- The truth is so complicated that nobody wants to hear it.

- If you know it, explain it to me.

- Maybe I have left in order not to see it either. Reality, looked at up close, is a very ugly sight.

- I don't think that you could live with your eyes closed.

- And why not? The majority of people do so, and it isn't hard. I don't mean people outside of Spain who may not be aware of the war ... Even in Madrid I know of many people who have managed not to be informed of what is going on. They live perfectly normal lives, believe it or not.

(Molina 2009, 893-894; my translation)

Reality, looked at up close, is an ugly sight, and it is exactly this unpleasant and inconvenient experience that the Spanish public need to have in order to understand the preconditions and consequences of the Civil War as a historical and social event.

\section{Metareflection as a dialogical tool}

A special literary technique that is applied in the contemporary Spanish historical novel in order to challenge the generally accepted point of view and to represent a non-exclusive image of the 'other', is that of autoreflection or metafiction. Metafiction has become part of a general trend in contemporary Spanish narrative (Amago), and novels like Cercas's Soldados de Salamina and Eduardo Lago's Llámame Brooklyn (2006) are good examples of novels in which literary invention, memory and metafictional reflections become fused into one coherent discourse. But 
the most remarkable novel in this sense is probably Isaac Rosa's Otra maldita novela sobre la guerra civil (2007).

Rosa's novel is an ironically commented re-edition of his novel La mala memoria (1999), which thematizes the so-called 'treaty of oblivion' of the Spanish transition to democracy. In the late seventies a middle-aged writer is engaged to write a falsified biography of a presumably diseased politician, formerly a Francoist hardliner and in his later years a spokesman for democratic reforms. During the investigation, the protagonist uncovers some of the crimes committed by this politician during the Civil War, when he, among other actions, was responsible for the execution of all the male inhabitants of a small Andalusian village. This unpunished crime, and the Civil War as such, are symbolically represented by the fact that the village in the narrative present, some forty years after the crime, is a ghost village populated by the grieving and insane widows, now hidden away and forgotten in the mountains in Andalucía. The biographer finds the village and is horrified by the cruelty of the politician's acts, and he feels compelled to reject the job and tell the widow and the public what he has discovered. But in an allegory of the real political conditions that determined the Spanish Transition period, the politician, who turns out to be alive and well, enters the scene and uses his power to assure that the secret is kept.

The original novel, La mala memoria, exhibits the characteristics of historiographic metafiction, with the plot divided between the process of investigation situated in the present (that is, in 1977) and the reconstructed past of the Civil War. While the story belonging to the reconstructed past is axiologically parallel to the narrative template described by Todorov, the frame story from the period of the Transition is more ambivalent. The purpose of the biography the protagonist is engaged to write is to secure the late politician's posthumous reputation, but although the writer identifies with the political left, he initially sees no problem in taking on the job. In the process of rewriting the politician's life, this pragmatic attitude, characteristic of the political deception that followed the transition to democracy in Spain, the desengaño, is challenged, not only due to the cruelty of the crimes committed by the politician, but also because of the writing/investigation process itself. The protagonist was himself born in a small Andalusian village, and after the end of the war his father went into the mountains with a group of guerrillas, but one day the protagonist, who 
was only a little boy at the time, unwittingly led the Guardia civil to the guerrilla hideout. As an adult he cannot help feeling responsible for the arrest and subsequent execution of his father, and he has for many years tried to repress the memory and to adopt a pragmatic attitude. As he says: 'Each and every one of us has a dark spot in his past, a time that we would like to bury, that we consign to oblivion' (Rosa 2007, 326; my translation).

In the 2007 re-edition, the text of the original novel is commented on by a fictitious reader in italicized paragraphs after each chapter. In these metanarrative comments, the fictitious reader ironically scorns the author for his ambitious, florid style and his use of literary commonplaces, and he pinpoints some of the general traits of the contemporary novel dedicated to the rememorization of the Civil War: on the one hand the discourse between documentary journalism and fiction (Rosa 2007, 90, 363) and on the other the traditional representation of the Civil War as a continuation of an ancestral national tendency to fratricide (p. 260), which inevitably results in a Manichaean description of the evil Nationalist villain and the good Republican victims (pp. 300-302). The politician in the original text is described in the following terms: 'a bad guy like in the movies, in the bad movies. What we would call a villain. A terrible Bluebeard who kidnaps and abuses the little girls of the village ... Again, the evil. Not the interests, not the social confrontation, not the ideological fanaticism. No, the evil' (p. 301; my translation). In the eyes of the fictitious reader, who incarnates the voice of the implicit author eight years after the first edition of the original novel, this kind of prototypical narrative pattern is not adequate to the recovery of historical memory: 'We are afraid that, once again, the war, the memory, the victims and what was meant to be a cathartic novel, turn out to be an amusing story, an exercise of style ... Novels like this can do more harm than good in the construction of the discourse about the past, despite all the good intentions they declare' (pp. 444-445; my translation).

\section{Concluding remarks}

As Todorov suggests, it is necessary for literary fiction to break with the traditional narrative templates of good and evil in order to make a valuable contribution to collective memory - a contribution that will make a difference in the future. By drawing on the forms and conventions of 
historiographic metafiction, an important current within Spanish contemporary fiction has made an effort to do so in different ways.

While the point of view in the novel on the Civil War and immediate post-war experiences published in Spain during the period 1975-2000 seemed to identify exclusively with the Republican heroes and the defeated victims, which represented a simple inversion of the Francoist Manichaean point of view, the novel after the turn of the millennium has developed a multiperspectivist point of view which allows for a more subtle understanding of the cultural and social questions involved in the construction of cultural memory. My readings of the four novels indicate the different ways in which this multiperspectival point of view emerges. First, a series of novels attempts to understand the Nationalist point of view from within, whether through introspection or through biographical description, in order to humanize the character of the Nationalist villain. Second, some novels attempt to adopt the point of view of the non-belligerent majority, either through identification with ordinary people who try to make a living in the chaos of war, or through symbolic representation (the deserter, the child, and so on). The result is that the war is conceived of, not as a battle between right and wrong, good and evil, but as a brutal violation of the fundamental conditions of human life. Third, a few novels have taken up the challenge of representing the unjustified use of violence on the Republican side. This topic is very delicate because it has been used as a privileged argument in the propaganda of the extreme right, but it seems necessary for the democratic forces to engage this matter, if they actually do want to learn from history. And finally a series of novels has adopted the strategy of commenting on themselves as textual representations of historical events. Through this renovation of the general narrative templates used to conceptualize the experiences of Civil War and the postwar period, literary discourse might even be able to change some of the models that have dominated the other social discourses dedicated to the question of historical memory in Spain.

\section{NOTES}

1. Cuñado 2007,Labanyi 2008, González García 2009. According to MorenoNuño, 150 novels on this topic were published in Spain between 1996 and 2006, and this tendency has only increased during the last four years (Moreno-Nuño 2006, 77). 
2. Populist authors of books on historical issues like Pío Moa and César Vidal have been supported by international historians like Stanley G. Payne.

3. The question of the contribution of narrative fiction to the construction of the cultural memory of the Spanish Civil War is addressed by the research team engaged in the project 'The Novelized Memory - The Contribution of Literature to the Construction of Cultural Identity in Spain' (University of Aarhus, 2011-2013).

4. The historical novel of the eighties and nineties in Spain has been characterized in various ways by critics. Kohut speaks about 'the postmodern historical novel' while Albert and Pulgarín prefer Hutcheon's concept of 'historiographic metafiction', Fernández Prieto calls it the 'new historical novel', Rodríguez Pequeño speaks about 'novela histórica culturalista' and Luengo baptizes the subgenre 'novels with historic confrontation' (novela de confrontación histórica).

\section{BIBLIOGRAPHY}

Amago, S. 2006, True Lies. Narrative Self-Consciousness in the Contemporary Spanish Novel, Rosemont, Cranbury, N.J.

Albert, M. 1999, 'La guerra civil y el franquismo en la novela desde 1975', Iberoamericana, vol. 23, pp. 38-67.

Bertrand de Muñoz, M. 1994, La novela europea y americana y la guerra civil española, Ediciones Júcar, Madrid.

Cercas, J. 2001, Soldados de Salamina, Tusquets Editores, Barcelona.

Colmeiro, J. F. 2005, Memoria histórica e identidad cultural. De la postguerra a la postmodernidad, Anthropos, Barcelona.

Corral, P. 2009, La ciudad de arena, Aleph Editores, Barcelona.

Cossalter, F. 2006, 'A propósito de la escritura del pasado. Notas sobre la representación de la guerra civil', Cuadernos de Historia Contemporánea, vol. 28, pp. 359-367.

Cuñado, I. 2007, 'Despertar tras la amnesia: Guerra civil y postmemoria en la novela española del siglo XXI', Dissidences. Hispanic Journal of Theory and Criticism, vol. 3, available at http://www.dissidences.org/IndexTercerNumero.html (accessed 7 January 2011).

Chacón, D. 2002, La voz dormida, Alfaguara, Madrid.

Dalmau, M. 2009, La noche del Diablo, Anagrama, Barcelona.

Fernández Prieto, C. 1996, 'Poética de la novela histórica como género literario', Signa, vol. 5, available at http:/www.cervantesvirtual.com/servlet/SirveObras/ 01472845544836106454480/p0000003.htm\#I_13_(accessed 7 January 2011).

Fonseca, C. 2009, Tiempo de memoria, Temas de hoy, Madrid.

Gómez Trueba, T. 2009, 'Esa bestia omnívora que es el yo - el uso de la autoficción en la obra narrativa de Javier Cercas', Bulletin of Spanish Studies, vol. 86, no.1, pp. 67-83.

Gogorza Fletcher, M. 1974, The Spanish Historical Novel, Tamesis Books, London.

González García, J. M. 2009, 'Spanish literature and the recovery of historical memory', European Review, vol. 17, no. 1, pp. 177-185, available at http:// digital.csic.es/bitstream/10261/24972/1/European_Review.pdf (accessed 7 January 2011). 
Gracia García, J. 2004, La resistencia silenciosa. Fascismo y cultura en España, Anagrama, Barcelona.

-. 2008, 'Revisionism, a necessary evil', International Journal of Iberian Studies, vol. 21, no. 3, pp. 247-262.

Guirado, N. 2009, La lista de los catorce, Martínez Roca, Madrid.

Halbwachs, M. 1992, On Collective Memory, University of Chicago Press, Chicago, Ill.

Hutcheon, L. 1989, A Poetics of Postmodernism: History, Theory, Fiction, Routledge, New York.

Kohut, K. (ed.) 1997, La invensión del pasado. La novela histórica en el marco de la postmodernidad, Iberoamericana, Madrid.

Labanyi, J. 2008, 'The politics of memory in contemporary Spain', Journal of Spanish Cultural Studies, vol. 9, no. 2, pp. 119-125.

Lago, E. 2006, Llámame Brooklyn, Destino Libros, Barcelona.

Luengo, A. 2004, La encrucijada de la memoria. La memoria colectiva de la guerra civil española en la novela contemporánea, Tranvia, Berlin.

Martínez de Pisón, I. 2005, Enterrar a los muertos, Seix Barral, Barcelona.

Méndez, A. 2004, Los girasoles ciegos, Anagrama, Barcelona.

Moreno-Nuño, C. 2006, Las huellas de la guerra civil. Mito y trauma en la narrativa de la España democrática, Ediciones Libertarias, Madrid.

Muñoz Molina, A. 2001, Sefarad, Alfaguara, Madrid.

-. 2004, Ventanas de Maniatan, Seix Barral, Barcelona.

-. 2006, El viento de la luna, Seix Barral, Barcelona.

—. 2007, Días de diario, Seix Barral, Barcelona.

—. 2009, La noche de los tiempos, Seix Barral, Barcelona.

Navajas, G. 2007, 'La memoria en la novela y el cine contemporáneos' in Memoria literaria de la transición española, ed. G. Montero, Biblioteca Iberoamericana, Vervuert, Madrid.

Neumann, B. 2008, 'The literary representation of memory' in Cultural Memory Studies, ed. A. Erll \& A. Nünning, De Gruyter, New York.

Nora, P. (ed.) 1984-1992, Les lieux de mémoire, vols. 1-3, Gallimard, Paris.

Oleza Simó, J. 1996, 'Una nueva alianza entre historia y novela' in La novela histórica a finales del siglo $X X$, ed. R. Castillo, Visor, Madrid, pp. 81-95.

Orwell, G. 1938, Homage to Catalonia, available at http://www.george-orwell.org/ Homage_to_Catalonia/index.html (accessed 7 January 2011).

Payne, S. G. 2006, 40 preguntas fundamentales sobre la guerra civil, La Esfera de los Libros, Madrid.

Ponce de León, J. L. 1971, La novela española de la guerra civil (1936-39), Insula, Madrid.

Pulgarín Cuadrado, A. 1995, Metaficción historiográfica - La novela histórica en la narrativa hispánica postmodernista, Fundamentos, Madrid.

Resina, J. R. 2007, 'Faltos de memoria: La reclamación del pasado desde la transición española a la democracia' in Memoria literaria de la Transición española, ed. G. Montero, Biblioteca Iberoamericana, Vervuert, Madrid.

Rosa, I. 2007, Otra maldita novela sobre la guerra civil, Seix Barral, Barcelona.

Satorras Pons, A. 2003, 'Soldados de Salamina de Javier Cercas, reflexiones sobre los héroes', Revista Hispánica Moderna, vol. 56, no.1, pp. 227-245. 
Todorov, T. 2009, 'Memory as remedy for evil', Journal of International Criminal Justice, vol. 7, pp. 447-462.

Vidal, C. 2005, Paracuellos-Katyn: Un ensayo sobre el genocidio de la izquierda, Libros Libres, Madrid.

Hans Lauge Hansen (romhlh@hum.au.dk), born 1954, is associate professor in Hispanic literatures at Aarhus University, Denmark. His field of investigation is twentiethcentury Spanish literature, especially the poetry of the Generation of '27 and the contemporary novel. He is head of the research project 'La memoria novelada' ('The Novelized Memory'), which is dedicated to the study of contemporary literary discourse and its contribution to the construction of a cultural memory of the Civil War in Spain. The project is funded by the Danish National Research Council for the period 2011-2013. His most recent publications include 'Dialogic enunciation and migrant identity' in Llámame Brooklyn (2006), Anales de la Literatura Espanola Contemporanea (accepted for publication), 'La memoria del Diablo', Actas del XII Congreso del Instituto Internacional de Sociocritica (accepted for publication), 'Europa som utopi og dystopi hos Antonio Muñoz Molina', $K \& K$, vol. 108, 2009, and 'Una ciudad dilatada por la luz: La función del arte en la novelística de Antonio Muñoz Molina', Revue Romane (accepted for publication). 